\title{
A New Method of Pack Aluminization
}

\author{
T. Werber, L. Levin, A. Ginzburg, L. Klinger and A. Katsman \\ Department of Materials Engineering, Technion - \\ Israel Institute of Technology, Haifa, 32000, Israel
}

\begin{abstract}
Aluminium diffusion coatings are often prepared by using a pack aluminization technique, which is a specific variety of the CVD method. The coating process takes place in a bed containing a master alloy (MA) that serves as a source of the coating forming element (CFE). The phase composition of the diffusion layer obtained depends on the activity of the CFE during the pack aluminization processing. One of the methods to control the activity is a variation in the chemical composition of the MA. In this method the MA of the needed CFE concentration is also prepared by using the pack aluminization technique. So the pack aluminization technique is used twice during the processing cycle: once for MA preparation and once for coating. The method was applied to coating of iron with a layer of FeAl.
\end{abstract}

\section{INTRODUCTION}

Iron aluminides are signalized by an excellent corrosion resistance at elevated temperatures in aggressive atmospheres /1-4/. This enables steels and alloys to be protected by means of $\mathrm{Fe}-\mathrm{Al}$ intermetallic coatings.

In this work iron aluminide coatings were deposited on Iron Armko by pack aluminization. This technique is a specific variant of the CVD method. The coating process takes place in a bed containing a master alloy, which serves as the source of the element providing the coating. Master alloys are usually prepared by melting followed by homogenization and grinding into powder 15-8/. In this process some chemical and phase inhomogeneity arises, so that the effective activity of the bed differs from that originally intended.
In the present work a new method of master alloy preparation was elaborated, which consisted of producing the master alloy itself, too, by the pack aluminization technique, which is thus used twice during the processing cycle, viz. for the preparation of the master alloy and for coating. In this method, prior calculation permits regulation of the activity of the bed: a) using $\mathrm{Al}$ powder, which provides a high-activity bed; b) using $\mathrm{Fe}_{2} \mathrm{Al}_{5}$ or other intermetallics providing a lowactivity bed. The actual composition of the bed is selected on the basis of the Fe-Al phase diagram. In this manner the composition of the protective coating can be planned ahead.

\section{EXPERIMENTAL}

In the authors' experiments the intermetallic master alloy was produced from $\mathrm{Al}$ and $\mathrm{Fe}$ powders, following prior blending for $60 \mathrm{mins}$, at a temperature of $700^{\circ} \mathrm{C}$, the powders being of quantities sufficient for yielding $\mathrm{Fe}_{2} \mathrm{Al}_{5}, \mathrm{NH}_{4} \mathrm{Cl}$ serving as activator and alumina as filler.

Pack aluminization of the Iron Armko was applied at $700^{\circ} \mathrm{C}$ and at $900^{\circ} \mathrm{C}$ in a high-activity bed ( $\mathrm{Al}$ powder delivering the coating, $\mathrm{NH}_{4} \mathrm{CI}$ serving as the activator, alumina as filler), as well as in a low-activity bed at $900^{\circ} \mathrm{C}\left(\mathrm{Fe}_{2} \mathrm{Al}_{5}\right.$ as the source of the coating, activator and filler, as before). Some samples, packaluminized at $700^{\circ} \mathrm{C}$ in the high-activity bed, were heat-treated at $900^{\circ} \mathrm{C}$ with subsequent air-cooling.

The iron aluminide coatings were examined with the aid of optical microscopy, scanning electron microscopy with EDS, and X-ray analysis. X-ray and EDS analysis data match well in all the variants of the pack aluminization process studied as well as in those 
Table 1

Pack aluminization of Iron Armko

\begin{tabular}{|c|c|c|c|}
\hline $\begin{array}{l}\text { Temperature and } \\
\text { exposure at Pack } \\
\text { Aluminization }\end{array}$ & $\begin{array}{c}\text { Composition } \\
\text { of the } \\
\text { bed }\end{array}$ & $\begin{array}{l}\text { Composition } \\
\text { of the the } \\
\text { coating }\end{array}$ & $\begin{array}{l}\text { Thickness of } \\
\text { each } \\
\text { layer, } \mu \mathrm{m}\end{array}$ \\
\hline $700^{\circ} \mathrm{C}, 1.5 \mathrm{~h}$ & $\begin{array}{l}\mathrm{Al}+\mathrm{Al}_{2} \mathrm{O}_{3}+\mathrm{NH}_{4} \mathrm{Cl} \\
\text { (high-activity bed) }\end{array}$ & $\mathrm{Fe}_{2} \mathrm{Al}_{5}$ & 40 \\
\hline $900^{\circ} \mathrm{C}, 2.5 \mathrm{~h}$ & $\begin{array}{c}\mathrm{Al}+\mathrm{Al}_{2} \mathrm{O}_{3}+\mathrm{NH}_{4} \mathrm{Cl} \\
\text { (high-activity bed) }\end{array}$ & $\begin{array}{l}\mathrm{Fe}_{2} \mathrm{Al}_{5} \\
\mathrm{FeAl}_{2} \\
\mathrm{FeAl}\end{array}$ & $\begin{array}{c}\text { a few microns } \\
250 \\
50\end{array}$ \\
\hline $900^{\circ} \mathrm{C}, 2.0 \mathrm{~h}$ & $\begin{array}{l}\mathrm{Fe}_{2} \mathrm{Al}_{5}+\mathrm{Al}_{2} \mathrm{O}_{3}+\mathrm{NH}_{4} \mathrm{Cl} \\
\text { (low-activity bed) }\end{array}$ & $\begin{array}{l}\mathrm{FeAl}_{2} \\
\mathrm{FeAl} \\
\text { Solid Solution }\end{array}$ & $\begin{array}{l}8-10 \\
5-7 \\
12-15\end{array}$ \\
\hline $\begin{array}{l}\text { Pack Aluminization } \\
\text { at } 700^{\circ} \mathrm{C}, 1.5 \mathrm{~h} \text { and } \\
\text { heat treatment at } \\
900^{\circ} \mathrm{C}, 2.5 \mathrm{~h}\end{array}$ & - & $\begin{array}{l}\mathrm{Fe}_{2} \mathrm{Al}_{5} \\
\mathrm{FeAl}_{2} \\
\mathrm{FeAl} \\
\mathrm{Fe}_{3} \mathrm{Al} \\
\text { Solid Solution }\end{array}$ & 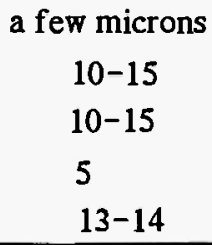 \\
\hline
\end{tabular}

specimens that were heat-treated. The results of the study are presented in Table 1 and in Figs. 1 - 3.

\section{DISCUSSION AND CONCLUSION}

In a high-activity bed at $700^{\circ} \mathrm{C}$, a $64 \mu \mathrm{m}$-thick $\mathrm{Fe}_{2} \mathrm{Al}_{5}$ intermetallic layer was formed on the surface of the specimen (see Fig. la). When the processing temperature was increased to $900^{\circ} \mathrm{C}$, a three-layered coating was observed on the surface of the specimen: the $\mathrm{Fe}_{2} \mathrm{Al}_{5}$ layer (a few microns thick), beneath this a $\sim 30 \mu \mathrm{m}$-thick layer of $\mathrm{FeAl}_{2}$, and a third layer, consisting of FeAl intermetallic $20 \mu \mathrm{m}$, thick (see Fig. lb).

In the low-activity bed at $900^{\circ} \mathrm{C}\left(\mathrm{Fe}_{2} \mathrm{Al}_{5}\right.$ used as $\mathrm{MA}$ ), a three-layered coating was again obtained, the following sequence of layers being observed (from the surface to the matrix): $\mathrm{FeAl}_{2}(8-10 \mu \mathrm{m}), \mathrm{FeAl}$ (5-7 $\mu \mathrm{m})$, solid solution $\mathrm{Al}$ in $\mathrm{Fe}(12-15 \mu \mathrm{m})$ (see Fig. 2a).

After heat treatment at $900^{\circ} \mathrm{C}$ for 2.5 hours, the one-layered $\mathrm{Fe}_{2} \mathrm{Al}_{5}$ coating (obtained at $700^{\circ} \mathrm{C}$ in a high-activity bed) was changed by diffusion into a polylayered coating, as follows (the layer positions shown from surface to matrix): $\mathrm{FeAl}_{2}(10-15 \mu \mathrm{m}), \mathrm{FeAl}(10$ $15 \mu \mathrm{m}), \mathrm{Fe}_{3} \mathrm{Al}(\sim 5 \mu \mathrm{m})$, solid solution $\mathrm{Al}$ in $\mathrm{Fe}(13-14$ $\mu \mathrm{m})$ (see Fig. 2b).

It is noteworthy that the sequence of the intermetallic layers corresponds to the sequence of phases given in the $\mathrm{Fe}-\mathrm{Al}$ equilibrium diagram: $\mathrm{Fe}_{2} \mathrm{Al}_{S}-$ $\mathrm{FeAl}_{2}-\mathrm{FeAl}-\mathrm{Fe}_{3} \mathrm{Al}$ - solid solution.

To conclude, by using an intermetallic of a certain composition as master alloy, the phase composition of the intermetallic coating on the surface of the coated alloy can be predetermined. 

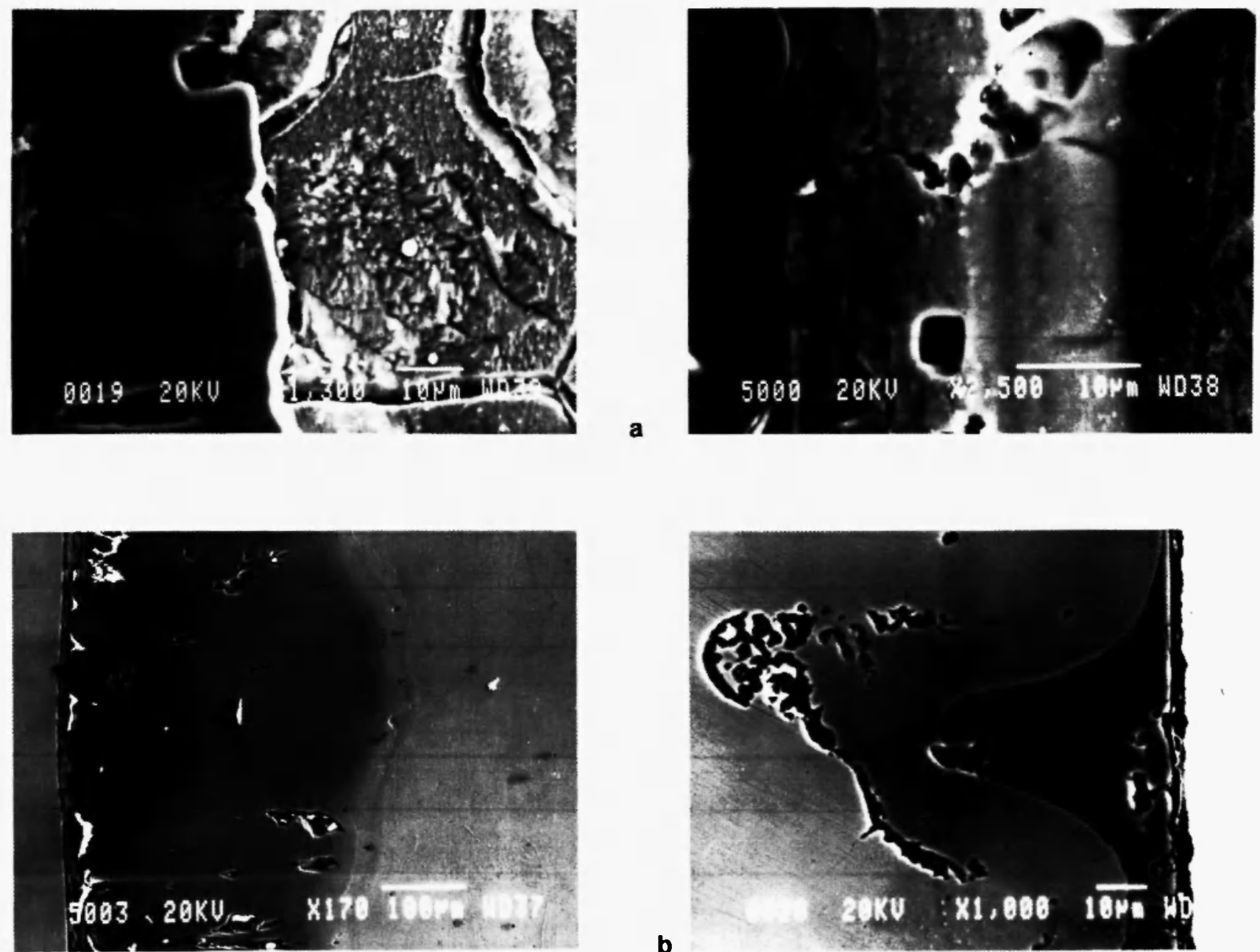

Fig. 1: SEM micrographs of the specimens after pack aluminization in high-activity bed
a) $700^{\circ} \mathrm{C}$
b) $900^{\circ} \mathrm{C}$

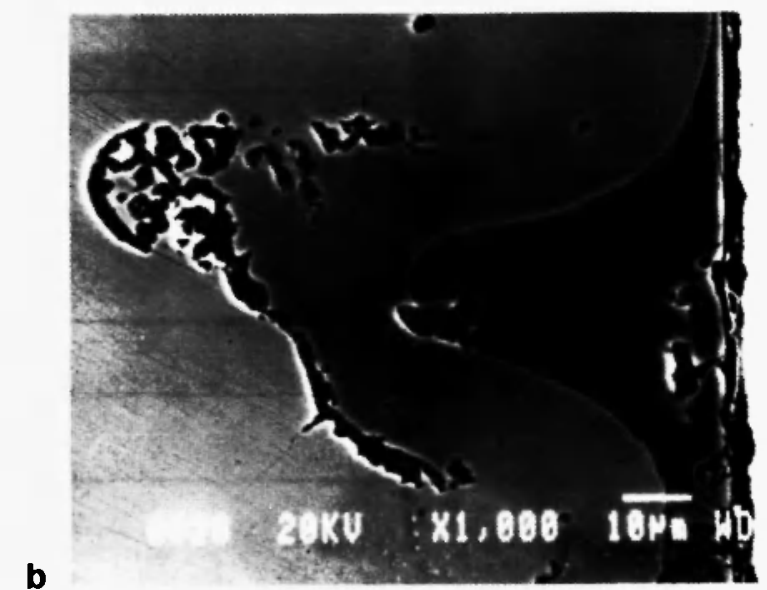

Fig. 2: SEM micrographs of the specimens after pack aluminization

a) low-activity bed, $900^{\circ} \mathrm{C}$

b) high-activity bed, $700^{\circ} \mathrm{C}$ and heat treatment at $900^{\circ} \mathrm{C}$. 

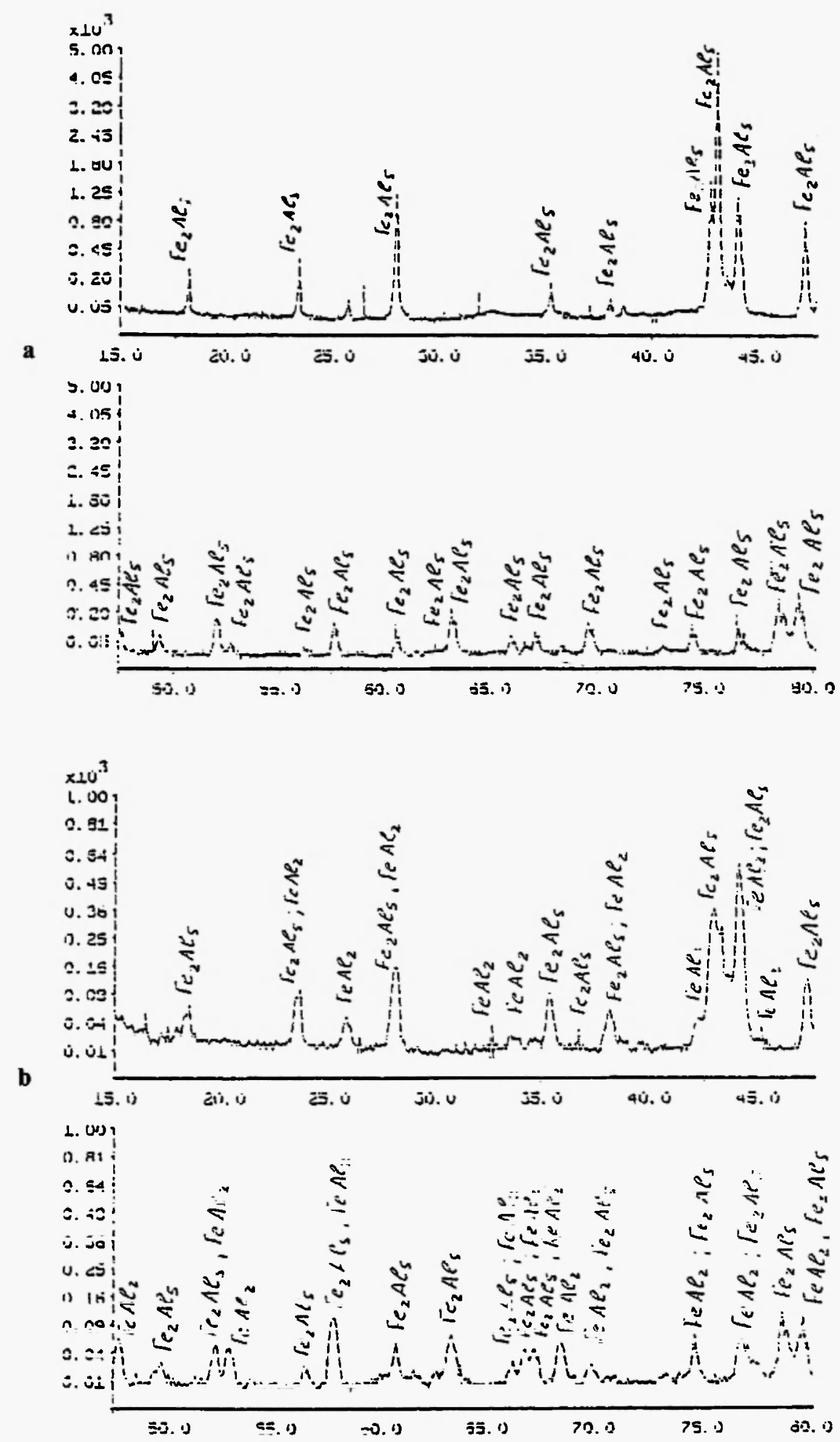

Fig. 3: $\mathrm{XRD} \mathrm{CuK}$ pattern from the specimens after pack aluminization in high-activity bed
a) $700^{\circ} \mathrm{C}$
b) $900^{\circ} \mathrm{C}$ 


\section{REFERENCES}

1. C.T. Liu and J.O. Stiegler, Metals Handbook, 10th ed., vol. 2, 913-925.

2. J.L. Smialek, J. Doychak and D.J. Gaydash, in: Oxidation of High-Temperature Intermetallics, $\mathrm{T}$. Grobstein and J. Doychak (eds.), publication of the Min. Met. \& Mat. Society, 1988; pp. 97-107.

3. G.H. Meier, in: Oxidation of High-Temperature Intermetallics, T. Grobstein and J. Doychak (eds.), publication of the Min. Met. \& Mat.. Society, 1988; pp. 1-6.

4. R. Streif, "Protection of materials by advanced hightemperature coatings", in: 3rd International Symposium on High-Temperature Corrosion and Protection of Materials, 1992; p. 95.
5. F.D. Geib and R.A. Rapp, "Diffusion coatings for iron aluminide $\left(\mathrm{Fe}_{3} \mathrm{Al}\right)$ via halide-activated pack cementation", in: Proc. Conf. on Processing and Fabrication of Advanced Materials for HighTemperature Applications, 1991; pp. 347-360.

6. R.A. Rapp, "Codeposition of elements in pack cementation diffusion coatings for various alloys", in: Proc. Conf. on Processing and Fabrication of Advanced Materials for High-Temperature Applications, 1992; p. 345.

7. Aruna Bahadur, T.L. Sharma, N. Parida and A.N. Mukherjee, J. Materials Science, 28, 5375-5381 (1993).

8. Th. Uihlein, W. Auer and G. Eggeler, Werkstoffe und Korrosion, 40, 29-33 (1989). 


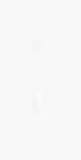

